\title{
Urinary excretion of magnesium and calcium as an index of absorption is not affected by lactose intake in healthy adults
}

\author{
BY ELIZABETH J. BRINK, EMERENTIA C. H. VAN BERESTEIJN \\ AND PIETER R. DEKKER \\ Department of Nutrition, Netherlands Institute for Dairy Research, PO Box 20,6710 BA Ede, \\ The Netherlands \\ AND ANTONC.BEYNEN \\ Department of Laboratory Animal Science, State University, Utrecht, The Netherlands and \\ Department of Human Nutrition, Agricultural University, Wageningen, The Netherlands
}

(Received 27 January 1992-Accepted 16 July 1992)

\begin{abstract}
The effect of lactose on the urinary excretion of $\mathrm{Mg}$ and $\mathrm{Ca}$, as an index of absorption, was studied in a double-blind, crossover study during three 1-week periods. Twenty-four healthy, lactose-tolerant, adult volunteers maintained their habitual diets with the exception that all lactose-containing dairy products in the diet were replaced by $600 \mathrm{~g} / \mathrm{d}$ of three specially prepared dairy products. These products were based on either lactose-enriched cow's milk or lactose-enriched, lactase $(E C$ 3.2.1.23)-treated cow's milk, with or without added $\mathrm{Mg}$, and were given in turn during 1 week. Lactose intake was increased by $127 \mathrm{mmol} / \mathrm{d}(46 \mathrm{~g} / \mathrm{d})$ while taking the lactose-enriched products. While taking the Mg-enriched products, $\mathrm{Mg}$ intake was increased by $2.8 \mathrm{mmol} / \mathrm{d}(69 \mathrm{mg} / \mathrm{d})$ which was equivalent to $17 \%$ of the habitual $\mathrm{Mg}$ intake. Apart from the lactose and $\mathrm{Mg}$ intake, nutrient intake was comparable during the three dietary periods. Urinary excretions of $\mathrm{Mg}$ and $\mathrm{Ca}$ were used as indicators for their absorption. $\mathrm{Mg}$ supplementation significantly increased urinary $\mathrm{Mg}$ excretion by $0.97 \mathrm{mmol} / \mathrm{d}$ (equivalent to an increase of $18 \%, P<0.001$ ), indicating that urinary $\mathrm{Mg}$ excretion is a valid indicator for intestinal $\mathrm{Mg}$ absorption. Hydrolysis of lactose did not affect urinary excretion of $\mathrm{Mg}$ and $\mathrm{Ca}$, which implies that lactose intake does not affect the absorption of $\mathrm{Mg}$ and $\mathrm{Ca}$ in healthy adults.
\end{abstract}

Lactose: Magnesium: Calcium: Humans

Marginal intakes and impaired intestinal absorption of $\mathrm{Mg}$ and $\mathrm{Ca}$ may contribute to the pathogenesis of osteoporosis, coronary heart disease and cancer (Shills, 1988; Berner et al. 1990). Thus, it is of interest to identify nutrients that either reduce or improve absorption of these minerals. The milk sugar lactose enhances intestinal absorption of $\mathrm{Mg}$ in rats (Fournier et al. 1971; Andrieux \& Sacquet, 1983; Schaafsma et al. 1988; Greger et al. 1989; Behling \& Gregor, 1990; Brink et al. 1991, 1992). Such an effect also occurs in infants (Kobayashi et al. 1975; Ziegler \& Fomon, 1983; Wirth et al. 1990), but it is not known whether lactose influences $\mathrm{Mg}$ absorption in adults. The effect of lactose on $\mathrm{Ca}$ absorption in rats and lactose-tolerant humans is controversial with both an improvement (Fournier, 1954; Fournier \& Dupuis, 1960; Vaughan \& Filler, 1960; Condon et al. 1970; Pansu \& Chapuy, 1970; Kocian et al. 1973; Pansu et al. 1975; Armbrecht \& Wasserman, 1979; Andrieux \& Sacquet, 1983; Cochet et al. 1983; Schaafsma et al. 1988; Greger et al. 1989) and no effect (Debognie et al. 1979; Greger et al. 1987; Sheikh et al. 1987; Recker et al. 1988 ) being reported.

The lack of conclusive information about the effect of lactose on the absorption of $\mathrm{Mg}$ and $\mathrm{Ca}$ in lactose-tolerant adult humans prompted us to perform the present study. We 
determined urinary excretion of $\mathrm{Mg}$ and $\mathrm{Ca}$ in adults given lactose-enriched cow's milk and cow's milk with hydrolysed lactose either without or with added $\mathrm{Mg}$ in a crossover design. The latter treatment served as a positive control for the detection of an increased urinary excretion of $\mathrm{Mg}$. Under steady-state conditions and at normal intakes of $\mathrm{Mg}$ and $\mathrm{Ca}$, urinary excretion of these minerals is a valid indicator for their absorption (Spencer et al. 1984; Morris et al. 1988).

\section{SUBJECTS AND METHODS}

\section{Subjects}

Twenty-four healthy subjects (fourteen males and ten females), all employees of The Netherlands Institute for Dairy Research, participated in the present study. Subjects were 21-43 years of age, 54-91 kg body weight, did not take any medication and were apparently lactose-tolerant. For this age-group it may be assumed that bone turnover is relatively stable. All participants gave their informed consent, and the study protocol was approved by the Medical Ethical Committee of the Wageningen Agricultural University. All participants completed the study.

\section{Experimental protocol}

The subjects were asked to maintain their usual lifestyle for the duration of the study. They were instructed to follow their habitual diet with the exception that all lactose-containing dairy products were replaced by specially prepared (see pp. 864-865) chocolate milk $(400 \mathrm{~g} / \mathrm{d})$ and vanilla custard $(200 \mathrm{~g} / \mathrm{d})$. These products were based on either lactoseenriched cow's milk or lactose-enriched, lactase (EC 3.2.1.23)-treated cow's milk with or without added $\mathrm{Mg}$. Lactose-enriched instead of normal milk products were used in order to limit the volume of the specially prepared dairy products that had to be consumed; the daily lactose intake from these products corresponded to 1 litre normal milk. The chocolate milk was consumed with breakfast $(200 \mathrm{~g} / \mathrm{d})$ and lunch $(200 \mathrm{~g} / \mathrm{d})$ and the vanilla custard with dinner $(200 \mathrm{~g} / \mathrm{d})$. The calculated daily lactose intake was $135.6 \mathrm{mmol} / \mathrm{d}$ from the lactose-enriched products and 8.6 (products without added $\mathrm{Mg}$ ) or $9.2 \mathrm{mmol} / \mathrm{d}$ (products with added $\mathrm{Mg}$ ) from the lactase-treated products. The calculated extra intake of $\mathrm{Mg}$ from the $\mathrm{Mg}$-enriched products was $3 \cdot 1 \mathrm{mmol} / \mathrm{d}$.

To eliminate any bias due to the attitudes of the subjects and investigators and to control for time trends and carry-over effects, a double-blind crossover design was used in which each treatment followed each other the same number of times. The subjects were divided into six groups of four individuals each. Each group underwent one of the six treatment orders. The groups were stratified for body weight, age and male: female ratio. Each dietary treatment was given for 1 week and the entire study was conducted over a period of 3 weeks. During each 1 -week period the subjects recorded their actual intake of nutrients on three arbitrary days (two working days and one weekend day) in specially designed diaries. Two samples of $24 \mathrm{~h}$ urine were collected; on days 5 and 7 each week. Body weight was measured once weekly.

\section{Experimental products}

The experimental dairy products were manufactured by the Technology Department of The Netherlands Institute for Dairy Research. Sterilized, semi-skimmed cow's milk was supplemented with $116 \mathrm{mmol}$ lactose/l (Pharmatose; DMV, Veghel, The Netherlands). Milk with hydrolysed lactose was prepared by adding $400 \mathrm{mg}$ (2000 neutral lactase units) lactase (Maxilact LX 5000; Gist-Brocades, Delft, The Netherlands) to 1 litre of this product. After incubation for $24 \mathrm{~h}$ at $10^{\circ}$, about $92 \%$ of the lactose was found to be 
Table 1. Analysed concentrations of nitrogen, fat, lactose and minerals ${ }^{*}$ in the experimental dairy products $\dagger$ (per $\mathrm{kg}$ product)

\begin{tabular}{|c|c|c|c|c|c|c|}
\hline \multirow[b]{2}{*}{$\begin{array}{l}\text { Component } \\
\text { (/kg product) }\end{array}$} & \multicolumn{3}{|c|}{ Chocolate milk } & \multicolumn{3}{|c|}{ Vanilla custard } \\
\hline & Control & $\begin{array}{l}\text { Lactose- } \\
\text { enriched }\end{array}$ & $\begin{array}{c}\mathrm{Mg}- \\
\text { enriched } 8\end{array}$ & Controlt & $\begin{array}{l}\text { Lactose- } \\
\text { enriched }\end{array}$ & $\begin{array}{c}\text { Mg- } \\
\text { enricheds }\end{array}$ \\
\hline$N(g)$ & $5 \cdot 5$ & $5 \cdot 5$ & $5 \cdot 4$ & $5 \cdot 0$ & $5 \cdot 1$ & $5 \cdot 0$ \\
\hline Fat $(\mathrm{g})$ & 17 & 17 & 16 & 15 & 14 & 15 \\
\hline Lactose (mmol) & 14 & 229 & 15 & 15 & 220 & 16 \\
\hline $\mathrm{Ca}(\mathrm{mmol})$ & $26 \cdot 3$ & 26.5 & $26 \cdot 1$ & $25 \cdot 0$ & $25 \cdot 2$ & $25 \cdot 3$ \\
\hline $\mathrm{Mg}(\mathrm{mmol})$ & $7 \cdot 2$ & $7 \cdot 2$ & $12 \cdot 0$ & $4 \cdot 0$ & $4 \cdot 0$ & $9 \cdot 7$ \\
\hline $\mathrm{P}(\mathrm{mmol})$ & $29 \cdot 6$ & $29 \cdot 7$ & $29 \cdot 5$ & $25 \cdot 4$ & $25 \cdot 5$ & $25 \cdot 6$ \\
\hline Water $(\mathrm{g})$ & 840 & 840 & 840 & 800 & 790 & 800 \\
\hline
\end{tabular}

hydrolysed. Part of the lactase-treated milk was supplemented with $\mathrm{MgCO}_{3}$ (Fluka, Buchs, Switzerland). In order to ensure a double-blind study design, chocolate milk and vanilla custard were prepared from the lactose-enriched milk, the lactose-enriched, lactase-treated milk and the lactose-enriched, lactase-treated, Mg-enriched milk using standard recipes. The analysed lactose and mineral concentrations in the experimental dairy products are given in Table 1.

\section{Analyses}

Nutrient intakes were calculated from the computerized Dutch food composition table (Stichting NEVO, 1989) with adjustments for the experimental dairy products. After appropriate dilution with a solution containing $\mathrm{SrCl}_{2}$ and $\mathrm{CsCl}$ (final concentrations 48 and $3 \mathrm{mmol} / \mathrm{l}$ respectively), the experimental products and urine samples were analysed for $\mathrm{Mg}$ and $\mathrm{Ca}$ by atomic absorption spectrophotometry (Perkin Elmer 1100; Bodenseewerk Perkin Elmer, Überlingen, Germany). P was determined by the Fiske \& Subbarow (1924) method. Lactose in the experimental dairy products was analysed by high performance liquid chromatography (Brons \& Olieman, 1983) and $\mathrm{N}$ by the macro-Kjeldahl method (International Dairy Federation, 1986). Urine was analysed for $\mathrm{Na}$ by atomic emission spectrophotometry (Perkin Elmer 1100). Urine samples were also analysed for creatinine and urea by a colorimetric method (Spayd et al. 1978; Goren et al. 1986) with the Ektachem 700 XR (Kodak, Rochester, New York, USA). The urinary excretion of minerals was expressed relative to that of creatinine.

\section{Statistics}

Changes in body weight and dietary and urinary variables were evaluated for statistically significant differences between males and females and between time-intervals by analysis of variance; no such differences $(P>0.99)$ were found. There were no significant differences in urinary mineral excretion between days 5 and 7 of urine collection $(P>0 \cdot 67$, Student's paired $t$ test) within dietary periods. The effects of lactose and $\mathrm{Mg}$ were then evaluated for pooled subjects and time-intervals with the use of Student's paired $t$ test. In case of urinary variables, average values of days 5 and 7 of each dietary period were used. The level of significance was pre-set at $P<0 \cdot 05$. On the basis of the observed variation in urinary $\mathrm{Mg}$ 
Table 2. Nutrient intake of subjects (n 24) when taking the lactose-enriched, lactase (EC 3.2.1.23)-treated products (control treatment), the lactose-enriched, or the lactoseenriched, lactase-treated, magnesium-enriched products $\dagger$

(Mean values with their standard errors)

\begin{tabular}{|c|c|c|c|c|c|c|}
\hline \multirow[t]{2}{*}{ Dietary treatment... } & \multicolumn{2}{|c|}{ Controlt } & \multicolumn{2}{|c|}{ Lactose-enriched } & \multicolumn{2}{|c|}{ Mg-enriched $\S$} \\
\hline & Mean & $\mathrm{SE}$ & Mean & SE & Mean & $\mathrm{SE}$ \\
\hline Energy $(\mathrm{MJ} / \mathrm{d})$ & 11.9 & $0 \cdot 4$ & 11.5 & 0.5 & $11 \cdot 5$ & 0.5 \\
\hline Protein ( $\%$ of energy) & $13 \cdot 9$ & $0 \cdot 4$ & $14 \cdot 0$ & $0 \cdot 4$ & $14 \cdot 2$ & $0 \cdot 3$ \\
\hline Fat ( $\%$ of energy) & $34 \cdot 1$ & 0.9 & $32 \cdot 9$ & $0 \cdot 9$ & $32 \cdot 6$ & $1 \cdot 3$ \\
\hline $\begin{array}{l}\text { Carbohydrates } \\
\text { (\% of energy) }\end{array}$ & $49 \cdot 7$ & $0 \cdot 9$ & $51 \cdot 3$ & $1 \cdot 2$ & $50 \cdot 4$ & $1 \cdot 4$ \\
\hline Lactose $(\mathrm{mmol} / \mathrm{d})$ & $8 \cdot 6$ & 0 & $135 \cdot 6^{*}$ & 0 & $9 \cdot 2$ & 0 \\
\hline Ethanol ( $\%$ of energy) & $2 \cdot 3$ & 0.6 & $2 \cdot 7$ & $0 \cdot 8$ & $2 \cdot 8$ & $0 \cdot 8$ \\
\hline Fibre $(\mathrm{g} / \mathrm{d})$ & $35 \cdot 8$ & $1 \cdot 6$ & 360 & $2 \cdot 0$ & $35 \cdot 2$ & $2 \cdot 2$ \\
\hline $\mathrm{Mg}(\mathrm{mmol} / \mathrm{d})$ & $16 \cdot 8$ & 0.7 & $17 \cdot 5$ & $0 \cdot 8$ & $19 \cdot 7^{*}$ & 0.6 \\
\hline $\mathrm{Ca}(\mathrm{mmol} / \mathrm{d})$ & $37 \cdot 0$ & 1.6 & $36 \cdot 4$ & $1 \cdot 7$ & $36 \cdot 8$ & 1.9 \\
\hline $\mathrm{P}(\mathrm{mmol} / \mathrm{d})$ & $62 \cdot 7$ & $2 \cdot 3$ & $62 \cdot 7$ & $2 \cdot 5$ & $62 \cdot 6$ & $2 \cdot 5$ \\
\hline $\mathrm{K}(\mathrm{mmol} / \mathrm{d})$ & 114 & 3 & 117 & 4 & 112 & 3 \\
\hline $\mathrm{Na}(\mathrm{mmol} / \mathrm{d})$ & 167 & 10 & 155 & 8 & 174 & 12 \\
\hline
\end{tabular}

Mean value was significantly different from those of other groups (one-sided, one-sample $t$ test): ${ }^{*} P<0.001$

$\dagger$ For details of products and procedures, see pp. 864-865.

Lactose-enriched, lactase-treated.

$\S$ Lactose-enriched, lactase-treated and supplemented with $\mathrm{Mg}$.

and $\mathrm{Ca}$ excretion it could be calculated that an increase in urinary $\mathrm{Mg}$ excretion of only $0.3 \mathrm{mmol} / \mathrm{d}$, corresponding to a lactose-induced increase in percentage apparent $\mathrm{Mg}$ absorption from the complete diet of $1 \cdot 8$, would reach statistical significance. For Ca these values were $0.5 \mathrm{mmol} / \mathrm{d}$ and $1.3 \%$ respectively.

\section{RESULTS \\ Body weight}

Body weight was not influenced by dietary treatments and remained stable throughout the experiment. Initial and final mean $(n 24)$ body weights $(\mathrm{kg})$ were $71.8($ SEM 1.9) and 71.7 (SEM 1.9) respectively.

\section{Nutrient intake}

Table 2 shows that the actual lactose intake was increased by $127 \mathrm{mmol} / \mathrm{d}$ after consumption of the lactose-enriched products. The actual $\mathrm{Mg}$ intake was significantly increased by $2.8 \mathrm{mmol} / \mathrm{d}$ during the period that the lactose-enriched, lactase-treated, $\mathrm{Mg}$ enriched products were consumed. This was associated with a negligible increase in lactose intake when compared with the lactose-enriched, lactase-treated period (control treatment). Otherwise, there were no significant differences in nutrient intake between the dietary periods.

\section{Urinary variables}

Urinary excretions of creatinine, urea, phosphate and Na were not significantly affected by increased lactose or increased $\mathrm{Mg}$ intake (Table 3). Likewise, extra lactose did not significantly influence the urinary excretion of $\mathrm{Mg}$ and $\mathrm{Ca}$. However, urinary $\mathrm{Mg}$ excretion 
Table 3. Urinary excretion of minerals by subjects (n 24) when taking the lactoseenriched, lactase (EC 3.2.1.23)-treated products (control treatment), the lactose-enriched, or the lactose-enriched, lactase-treated, magnesium-enriched products $\dagger$

(Mean values with their standard errors)

\begin{tabular}{|c|c|c|c|c|c|c|}
\hline & \multicolumn{2}{|c|}{ Control $\ddagger$} & \multicolumn{2}{|c|}{ Lactose-enriched } & \multicolumn{2}{|c|}{ Mg-enriched } \\
\hline & Mean & $\mathrm{SE}$ & Mean & $\mathrm{SE}$ & Mean & $\mathrm{SE}$ \\
\hline Volume $(\mathrm{l} / \mathrm{d})$ & $1 \cdot 39$ & $0 \cdot 09$ & 1.40 & $0 \cdot 11$ & $1 \cdot 41$ & $0 \cdot 08$ \\
\hline Creatinine $(\mathrm{mmol} / \mathrm{d})$ & $14 \cdot 1$ & 0.5 & $14 \cdot 0$ & 0.5 & $13 \cdot 8$ & 0.6 \\
\hline Urea $(\mathrm{mmol} / \mathrm{d})$ & 402 & 14 & 400 & 16 & 403 & 18 \\
\hline $\mathrm{Mg}$ :creatinine (mmol/mmol) & 0.38 & $0 \cdot 02$ & 0.37 & $0 \cdot 01$ & $0.46^{*}$ & 0.02 \\
\hline Ca:creatinine $(\mathrm{mmol} / \mathrm{mmol})$ & $0 \cdot 32$ & 0.03 & $0 \cdot 31$ & 0.03 & $0 \cdot 32$ & $0-02$ \\
\hline $\mathrm{P}:$ creatinine $(\mathrm{mmol} / \mathrm{mmol})$ & $2 \cdot 20$ & 0.07 & $2 \cdot 22$ & 0.07 & $2 \cdot 19$ & 0.08 \\
\hline Na :creatinine $(\mathrm{mmol} / \mathrm{mmol})$ & $11 \cdot 2$ & $0 \cdot 5$ & $11 \cdot 1$ & $0 \cdot 7$ & $11 \cdot 8$ & $0 \cdot 9$ \\
\hline
\end{tabular}

Mean value was significantly different from those of other groups (one-sided, one-sample $t$ test): ${ }^{*} P<0 \cdot 001$.

$\dagger$ For details of products and procedures, see pp. 864 865 .

$\ddagger$ Lactose-enriched, lactase-treated.

$\S$ Lactose-enriched, lactase-treated and supplemented with $\mathrm{Mg}$.

was significantly increased when the lactose-enriched, lactase-treated, Mg-enriched products were consumed.

\section{DISCUSSION}

Total mineral absorption equals the sum of mineral retention in the body, faecal endogenous excretion, urinary excretion and loss of the mineral via the skin. Therefore, three assumptions underlie the use of urinary mineral excretion as an index of absorption. First, it is assumed that mineral retention in the body is zero. This relates to the assumption that the adults participating in the present study were, in view of their age, in a steady state. Further, it is assumed that faecal endogenous excretion and the loss via the skin were constant. Thus, differences in urinary $\mathrm{Mg}$ excretion should reflect differences in $\mathrm{Mg}$ absorption. Indeed, a positive relationship between absorption and urinary excretion of $\mathrm{Mg}$ has been demonstrated (Morris et al. 1988). The moderately increased $\mathrm{Mg}$ intake $(2.8 \mathrm{mmol} / \mathrm{d}$; Table 2$)$ while consuming the lactose-enriched, lactase-treated, $\mathrm{Mg}$-enriched products caused an increase in urinary $\mathrm{Mg}$ excretion of $0.97 \mathrm{mmol} / \mathrm{d}$ (calculated from Table 3). Thus, urinary $\mathrm{Mg}$ excretion as a percentage of intake from the $\mathrm{Mg}$-enriched experimental dairy products was 35 . Reported percentages of $\mathrm{Mg}$ absorption range from 30 to 40 (Nordin, 1976; Shills, 1984) at a common intake of 10-20 mmol/d. Apparently, a treatment period of 1 week was long enough to demonstrate effects of a diet change.

The lack of an effect of lactose on $\mathrm{Mg}$ absorption, as assessed by urinary $\mathrm{Mg}$ excretion, in our study is at variance with findings of similar studies with infants (Kobayashi et al. 1975; Ziegler \& Fomon, 1983; Wirth et al. 1990). Kobayashi et al. (1975) reported that lactase-treated lactose increased $\mathrm{Mg}$ absorption compared with untreated lactose. This is an unexpected finding. However, $\mathrm{Mg}$ intake was not reported and differences in $\mathrm{Mg}$ intake between experimental groups cannot be excluded. Wirth et al. (1990) reported that lactose increases $\mathrm{Mg}$ absorption, but lactose ingestion was associated with an increased $\mathrm{Mg}$ intake. As shown in our study and in others (Hodgkinson \& Heaton, 1965; Schwartz et al. 1973), a higher $\mathrm{Mg}$ intake by itself results in increased absolute absorption and urinary excretion of $\mathrm{Mg}$ so that an independent effect of lactose cannot be determined. 
As mentioned previously (p. 863), dietary lactose increases intestinal absorption of $\mathrm{Mg}$ in rats. Rats become lactase deficient after weaning (De Groot \& Hoogendoorn, 1957) and, thus, are not capable of hydrolysing lactose in the intestine. Possibly, microbial fermentation of lactose in the intestine lowers lumen $\mathrm{pH}$. This would result in increasing solubility of intestinal $\mathrm{Mg}$ (Shiga et al. 1987), leading to enhanced $\mathrm{Mg}$ absorption (Hardwick et al. 1991).

There is controversy about the influence of lactose on $\mathrm{Ca}$ absorption in humans (Fournier \& Dupuis, 1960; Condon et al. 1970; Pansu \& Chapuy, 1970; Kocian et al. 1973; Cochet et al. 1983; Sheikh et al. 1987; Recker et al. 1988). In our lactose-tolerant subjects, hydrolysing lactose did not affect $\mathrm{Ca}$ absorption as assessed by urinary $\mathrm{Ca}$ excretion. It is possible that the 1-week treatment period was too short to observe an effect of lactose on urinary $\mathrm{Ca}$ excretion. However, it has been demonstrated that a change in dietary $\mathrm{Ca}$ or protein affects urinary Ca excretion within 1 week (Adams et al. 1979; van Beresteijn et al. 1990).

It has been shown that lactose increases $\mathrm{Ca}$ absorption in lactose-tolerant subjects, whereas it causes a decrease in lactose-intolerant subjects (Condon et al. 1970; Pansu \& Chapuy, 1970; Cochet et al. 1983). Others (Kobayashi et al. 1975; Debognie et al. 1979) demonstrated that hydrolysed lactose produces higher rates of $\mathrm{Ca}$ absorption than intact lactose. These findings indicate that hydrolysis of lactose in the intestine is a prerequisite for increased Ca absorption. In keeping with this, Birlouez-Aragon (1988) showed that after milk consumption lactose-intolerant subjects absorb less Ca than lactose-tolerant subjects. Furthermore, compared with normal milk, lactase-treated milk enhanced $\mathrm{Ca}$ absorption in lactose-intolerant subjects but had no effect in lactose-tolerant subjects (Birlouez-Aragon, 1988). The present study supports the latter observation. In lactosetolerant young adults with a high $\mathrm{Ca}$ intake, intact lactose had no specific effect on $\mathrm{Ca}$ absorption, as assessed by urinary excretion, when compared with its galactose and glucose components.

Urinary $\mathrm{Ca}$ excretion as a percentage of intake from the whole diet was on average 12. Reported percentages of Ca absorption range from 20 to 30 (Nordin, 1976) at a common intake of $20-25 \mathrm{mmol} / \mathrm{d}$ for $\mathrm{Ca}$. The low value observed in our experiment might be largely explained by the high $\mathrm{Ca}$ intake of $37 \mathrm{mmol} / \mathrm{d}$. Heaney et al. (1990) showed that an increase in $\mathrm{Ca}$ intake markedly decreased the absorption efficiency for $\mathrm{Ca}$. On the other hand, $\mathrm{Ca}$ absorption might have been underestimated in this study as $\mathrm{Ca}$ retention and $\mathrm{Ca}$ losses via the endogenous route and the skin were assumed to be negligible. However, $\mathrm{Ca}$ intake was equal for each dietary period (Table 2 ) and, thus, the low urinary Ca excretion relative to intake is not likely to have affected the treatment comparisons.

Our study cannot exclude long-term effects of lactose on mineral absorption, neither can it exclude an effect in other age-groups. These aspects need further investigation. However, our findings indicate that hydrolysing lactose does not affect urinary excretion of $\mathrm{Mg}$ and $\mathrm{Ca}$, which implies that lactose intake does not affect the absorption of $\mathrm{Mg}$ and $\mathrm{Ca}$ in healthy, lactose-tolerant adults.

Without the enthusiastic cooperation of the participants this study would not have been possible. The authors thank Joke van der Heiden-Winkeldermaat and Roald Neeter for their assistance with nutritional analyses, and Roelof van der Meer for valuable discussions and for his critical comments.

\section{REFERENCES}

Adams, N. D., Gray, R. W.\& Lemann, J. (1979). The effects of oral $\mathrm{CaCO}_{3}$ loading and dietary deprivation on plasma 1,25-dihydroxy-vitamin D concentrations in healthy adults. Journal of Clinical Endocrinology and Metabolism 48, 1008-1016. 
Andrieux, C. \& Sacquet, E. (1983). Effect of microflora and lactose on the absorption of calcium, phosphorus and magnesium in the hindgut of the rat. Reproduction Nutrition Développement 23, 258-271.

Armbrecht, H. \& Wasserman, R. (1979). Enhancement of $\mathrm{Ca}^{2+}$ uptake by lactose in the rat small intestine. Journal of Nutrition 106, 1265-1271.

Behling, A. R. \& Greger, J. L. (1990). Importance of lactose in yoghurt for mineral utilization. Journal of Agricultural and Food Chemistry 38, 200-204.

Berner, L. A., McBean, L. D. \& Lofgren, P. A. (1990). Calcium and chronic disease prevention: challenges to the food industry. Food Technology 44, 50-70.

Birlouez-Aragon, I. (1988). Effect of lactose on calcium absorption during duodenal milk perfusion. Reproduction Nutrition Développement 28, 1465-1472.

Brink, E. J., Dekker, P. R., van Beresteijn, E. C. H. \& Beynen, A. C. (1991). Inhibitory effect of dietary soybean protein vs casein on magnesium absorption in rats. Journal of Nutrition 121, 1373-1381.

Brink, E. J., Dekker, P. R., van Beresteijn, E. C. H. \& Beynen, A. C. (1992). Bioavailability of magnesium and calcium from cow's milk and soya-bean beverage in rats. British Journal of Nutrition, 68, 271-282.

Brons, C. \& Olieman, C. (1983). Study of high-performance liquid chromatographic separation of reducing sugars applied to the determination of lactose in milk. Journal of Chromatography 259, 79-86.

Cochet, B., Jung, A., Griessen, M., Bartholdi, P., Schaller, P. \& Donath, A. (I983). Effects of lactose on intestinal calcium absorption in normal and lactase-deficient subjects. Gastroenterology 84, 935-940.

Condon, J., Nassim, J. R., Hilbe, A., Millard, F. J. H. \& Stainhope, E. M. (1970). Calcium and phosphorus metabolism in relation to lactose tolerance. Lancet 16, 1027-1029.

Debognie, J. C., Newcomer, A. D., McGill, D. B. \& Phillips, S. F. (1979). Absorption of nutrients in lactase deficiency. Digestive Diseases and Sciences 24, 225-231.

De Groot, A. P. \& Hoogendoorn, P. (1957). The detrimental effect of lactose. II. Quantitative lactase determinations in various mammals. Netherlands Milk and Dairy Journal 11, 290-303.

Fiske, C. H. \& Subbarow, Y. (1924). The colorimetric determination of phosphorus. Journal of Biological Chemistry 66, 375-400.

Fournier, P. (1954). L'effet protecteur du lactose vis-à-vis du squelette de la ratte allaitante (Protecting effect of lactose on the skeletal growth of the weanling rat). Academic Sciences 238, 509-511.

Fournier, P. \& Dupuis, Y. (1960). Pouvoir antirachitique de composés divers dits de structure lactose, glucosamine, L-xylose, mannitol (Anti-rickets effects of lactose, glucosamine, L-xylose and mannitol). Academic Sciences 250, 3050-3052.

Fournier, P., Dupuis, Y. \& Fournier, Y. (1971). Effect of lactose on the absorption of alkaline earth metals and intestinal lactase activity. Israel Journal of Medical Sciences 7, 103-107.

Goren, M. P., Osborne, S. \& Wright, R. K. (1986). A peroxidase coupled kinetic enzymatic procedure evaluated for measuring serum and urinary creatinine. Clinical Chemistry 32, 548-551.

Greger, J. L., Gutkowski, C. M. \& Khazen, R. R. (1989). Interactions of lactose with calcium, magnesium and zinc in rats. Journal of Nutrition 119, I691-1697.

Greger, J. L., Krzykowski, C. E., Khazen, R. R. \& Krashoc, C. (1987). Mineral utilization by rats fed commercially available calcium supplements or milk. Journal of Nutrition 117, 717-724.

Hardwick, L. L., Jones, M. R., Brautbar, N. \& Lee, D. B. N. (1991). Magnesium absorption: mechanisms and the influence of vitamin D, calcium and phosphate. Journal of Nutrition 121, 13-23.

Heaney, R. P., Weaver, C. M. \& Fitzsimmons, M. L. (1990). Influence of calcium load on absorption fraction. Journal of Bone and Mineral Research 11, 1135-1138.

Hodgkinson, A. \& Heaton, F. W. (1965). The effect of food ingestion on the urinary excretion of calcium and magnesium. Clinica Chimica Acta 11, 354-362.

International Dairy Federation (1986). Determination of nitrogen content (Kjeldahl method) and calculation of crude protein content. International IDF standard 20A. Brussels: International Dairy Federation.

Kobayashi, A., Kawai, S., Ohbe, Y. \& Nagashima, Y. (1975). Effects of dietary lactose and a lactase preparation on the intestinal absorption of calcium and magnesium in normal infants. American Journal of Clinical Nutrition 28, 681-683.

Kocian, J., Skala, I. \& Bakos, K. (1973). Calcium absorption from milk and lactose-free milk in healthy subjects and patients with lactose intolerance. Digestion 9, 317-324.

Morris, E. R., Ellis, R., Stecle, P. \& Moser, P. B. (1988). Mineral balance of adult men consuming whole or dephytinized bran. Nutrition Research 8, 445-458.

Nordin, B. E. C. (1976). Calcium, Phosphate and Magnesium Metabolism. New York: Churchill Livingstone.

Pansu, D. \& Chapuy, M. (1970). Calcium absorption enhancement by lactose and xylose. Calcified Tissue Research 4, 155-156.

Pansu, D., Chapuy, M. C., Milani, M. \& Bellaton, C. (1975). Transepithelial calcium transport enhanced by xylose and glucose in the rat ligated loop. In Proceedings of the XIth European Symposium on Calcified Tissue, pp. 45-51 [P. Mielsen and E. Hjoring-Hanson, editors]. Copenhagen: Fald's.

Recker, R. R., Bammi, A., Barger-Lux, M. J. \& Heaney, R. P. (1988). Calcium absorbability from milk products, an imitation milk and calcium carbonate. American Journal of Clinical Nutrition 47, 93-95.

Schaafsma, G., Dekker, P. R. \& De Waard, H. (1988). Nutritional aspects of yogurt. 2. Bioavailability of essential minerals and trace elements. Netherlands Milk and Dairy Journal 42, 135--146. 
Schwartz, R., Walker, G., Linz, M. D. \& MacKellar, I. (1973). Metabolic responses of adolescent boys to two levels of dietary magnesium and protein. I. Magnesium and nitrogen retention. American Journal of Clinical Nutrition 26, 510-518.

Sheikh, M. S., Santa Ana, C. A., Nicar, M. J., Schiller, L. R. \& Fordtran, J. S. (1987). Gastrointestinal absorption of calcium salts. New England Journal of Medicine 317, 532-536.

Shiga, A., Sasaki, T. \& Horii, N. (1987). Correlations among pH and $\mathrm{Mg}, \mathrm{Ca}, \mathrm{P}, \mathrm{Na}, \mathrm{K}, \mathrm{Cl}^{-}$and $\mathrm{HCO}_{3}{ }^{-}$contents of digesta in the gastrointestinal tract. Japanese Journal of Veterinary Sciences 49, 973-979.

Shills, M. E. (1984). Magnesium. In Nutrition Reviews. Present Knowledge in Nutrition, 5th ed., pp. 422-438 [R. E. Olsen, H. P. Broquist, C. O. Chichester, W. J. Darby, A. C. Kolbye and R. M. Stalvey, editors]. Washington, DC: Nutrition Foundation.

Shills, M. E. (1988). Magnesium in health and disease. Annual Reviews of Nutrition 8, 429-460.

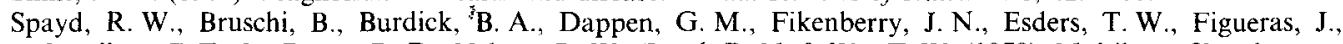
Goodhye, C. T., La Rossa, D. D., Nelson, R. W., Rand, R. N. \& Wu, T. W. (1978). Multilayer film elements for clinical chemistry. Clinical Chemistry 24, 1343-1344.

Spencer, H., Kramer, L. \& Osis, D. (1984). Effect of calcium on phosphorus metabolism in man. American Journal of Clinical Nutrition 40, 219-225.

Stichting NEVO (1989). Nederlandse voedingsstoffen bestand, NEVO-Tabel 1989/1990. 's-Gravenhage, The Netherlands: Voorlichtingsbureau voor de Voeding.

van Beresteijn, E. C. H., Brussaard, J. H. \& van Schaik, M. (1990). Relationship between the calcium-to-protein ratio in milk and the urinary calcium excretion in healthy adults - a controlled crossover study. American Journal of Clinical Nutrition 52, 142-146.

Vaughan, O. \& Filler, J. (1960). The enhancing action of certain carbohydrates on the intestinal absorption of calcium in rats. Journal of Nutrition 71, 10-14.

Wirth, F. H. Jr, Numerof, B., Pleban, P. \& Neylan, M. J. (1990). Effect of lactose on mineral absorption in preterm infants. Journal of Pediatrics 117, 283-287.

Ziegler, E. E. \& Fomon, S. J. (1983). Lactose enhances mineral absorption in infancy. Journal of Pediatrics 2 , $288-294$ 